Ann. Biol. anim. Bioch. Biophys., 1979, 19 (1A), 31-44.

\title{
Effect of stress on the course of labor and parturition time in normal or adrenalectomized rats
}

\author{
par M. J. BOSC, Agnès NICOLLE
}

Station de Physiologie de la Reproduction, I. N. R. A. Nouzilly 37380 Monnaie, France.

Summary. We report two experiments studying the effect of stress on the course of labor and on the time of parturition in the parturient rat. In the first experiment, different stresses were applied after expulsion of the first fefus. A simple manipulation of the female or a change of territory did not modify the whole expulsion phase but increased variability in the birth of the second fetus. By comparison, a strong stress lengthened the duration of expulsion and influenced the time intervals between the first births. A comparison of these results with those obtained after adrenalectomy indicated that the inhibitory effect of a strong stress was probably due to maternal adrenal epinephrin secretion. In the second experiment, a stress was applied before labor in normal rats submitted to two light régimes. In these conditions, the treatment essentially stimulated the last parturitions, which occurred earlier than in control animals.

The course of labor and the time of fetal expulsion are known to be influenced by an environmental change or by any event felt as stress. The bitch, for example, often has a labor affected by a disturbance of its usual life conditions (Bleicher, 1962 ; Freak, 1962). In domestic animals such as the pig (Signoret, 1969) or mare (Rossdale and Short, 1967), supervision is commonly known to influence the hourly distribution of parturitions during the day. Recently, Naaktgeboren and Bontekoe (1976) have reported cases of delayed births due to a stress at the onset of expulsion phase of labor in one rat, and in ferrets and sows. They have also demonstrated that a stress during labor results in temporary inhibition of uterine motility in sheep and rabbits. Most of these observations suggest that stress has an inhibitory effect at the time of birth. However, in mice it has been shown that stress causes the speed of the expulsion phase to vary more and the time of appearance of the first fetus to be stimulated (Newton et al., 1966 ; Newton et al., 1968).

In order to define the effects of stress during the parturient period and to study the possible interaction of general environmental conditions, we carried out two experiments using rats. In the first experiment, different stresses were applied during the late phase of labor in normal and adrenalectomized animals. In the second one, two groups of animals were submitted to two different light régimes and stressed before the onset of labor. 


\section{Material and methods.}

a) Rats of theWistar strain were used in these experiments. They were housed in rooms $(4.5 \times 2 \mathrm{~m})$ controlled for light (14 hrs light, $10 \mathrm{hrs}$ darkness) and temperature $\left(22^{\circ} \mathrm{C} \pm 1\right)$, and had free access to food and water. At 70 to 90 days of age, the females were caged with males overnight. After mating, they were isolated in individual boxes $(30 \times 45 \times 20 \mathrm{~cm})$ during the whole pregnancy; successful mating was confirmed by the presence of spermatozoa in the vaginal smear (day 1 of pregnancy). The animals were permitted two pregnancies.

b) Experiment 1. - The 170 animals used in this experiment were divided into two groups. The first group was split, as follows, into 5 lots of normal rats according to the type of stress applied and its time of application : 1 stress-free lot $(N), 3$ lots with a stress after expulsion of the first fetus (lots $\mathrm{Sm}, \mathrm{Smc}, \mathrm{S}$ ) and 1 lot with a stress after expulsion of the fourth fetus (lot $\mathrm{Sm} 4 \mathrm{c}$ ). Stress $\mathrm{Sm}$ was a simple manipulation of the rat for 20 seconds; stress Smc or $\mathrm{Sm} 4 \mathrm{c}$ included putting the rat with its pup in a new box after the manipulation; stress $S$ was a $0.1 \mathrm{ml}$ subcutaneous injection of a $10 \mathrm{p} .100$ formalin solution. As judged by corticosterone secretion, the latter stress $S$ may be considered as stronger than the first ones ( $\mathrm{Sm}, \mathrm{Smc}, \mathrm{Sm4c}$ ) (Van Goch ef al., 1963 ; Jego et al., 1971).

The second group of animals was divided into 3 lots of adrenalectomized rats which were compared to the normal rats submitted or not to stress $S$. The adrenalectomized females in this group received a subcutaneous injection of physiological saline (lot $A^{-}$), the formalin solution (lot $A^{-}+S$ ) or $5 \mu \mathrm{g}$ of epinephrin (lot $A^{-}+E$ ) after expulsion of the first fetus. Adrenalectomy was performed before mating under anesthesia and via a dorsal incision. Each gland was removed by blunt dissection using a curved forceps. After surgery, only saline water $(9 \mathrm{~g} / \mathrm{l})$ was given. The animals retained for analysis were those in which the absence of adrenal tissue had been verified after examination of the surgical area and determination of the plasma corticosteroid level, according to Guillemin et al. (1958), Thoman ef al. (1970) and Rakoto-Ratsimamanga et al. (1974). Blood samples for the latter determinations were collected under anesthesia 1 or 2 days after parturition and assayed with the fluorimetric technique of Guillemin et al. (1958) modified by Vernikos-Danellis ef al. (1966). During the experiment, the time of fetal expulsion was checked by continuous observation of the parturient animals.

c) Experiment 11. 301 pregnant rats were allotted to 2 groups according to the light régime used after mating : one was the normal régime used in our colony (14L-10D), the other was $8 \mathrm{hrs}$ light and $16 \mathrm{hrs}$ darkness (8L-16D). Two lots were constituted under a short-light period (8L-16D) : one control lot, and one given a stress at $10 \mathrm{a}$. $\mathrm{m}$. On day 22 of pregnancy. Three lots were constituted under the normal regime : one control lot, one given a stress at $10 \mathrm{a}$. $\mathrm{m}$. on day 22 of pregnancy, and a third lot given a stress at the same gestation stage followed by a second stress at $6 \mathrm{a} . \mathrm{m}$. on day 23. The stress in this experiment consisted of a 1-minute inhalation of an ethersaturated atmosphere under a glass case. In order to defermine the onset of expulsion, the birth of pups was recorded every hour during days 22 and 23 of pregnancy. 
d) For both experiments, the number of live or stillborn young rats was counted in each litter at the end of parturition ; prolificacy, the proportion of stillbirths and distribution of the expulsion intervals or of parturitions were studied using variance and Chi-square analyses (Snedecor and Cochran, 1957).

\section{Results.}

\section{A) Experiment 1 .}

Prolificacy did not differ between the lots of normal rats in the first group; mean litter size was $11.2 \pm 1.9$. This was slightly higher than that of adrenalectomized animals which was $10.3 \pm 1.8(0.05<P<0,01)$. But there was no difference between the lots of second group adrenalectomized females $(P>0.05)$ (table 1$)$.

TABLE 1

Prolificacy. Stillbirth rafes and duration of expulsion phase in normal or adrenalectomized rats submitted to different stresses ofter expulsion of 1 st or 4 th fetus (Experiment I)

\begin{tabular}{|c|c|c|c|c|c|c|c|c|}
\hline Lots & $N$ & $\mathrm{Sm}$ & Smc & $\mathrm{Sm} 4 \mathrm{c}$ & S. & $A^{-}$ & $\mathrm{A}^{-}+\mathrm{S}$ & $A-+E$ \\
\hline 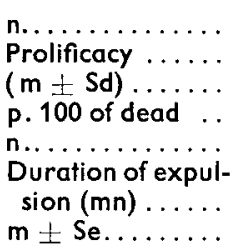 & $\begin{array}{c}22 \\
11.9 \\
\pm 1.5 \\
1.53 \\
22 \\
104.5 \\
\pm 9.5\end{array}$ & $\begin{array}{c}22 \\
11.4 \\
\pm 1.6 \\
2.78 \\
22 \\
\\
110.8 \\
\pm 16.4\end{array}$ & $\begin{array}{c}37 \\
10.5 \\
\pm 1.9 \\
2.82 \\
37 \\
109.4 \\
\pm 7.8\end{array}$ & $\begin{array}{c}24 \\
11.3 \\
\pm 2.2 \\
2.57 \\
24 \\
\\
115.4 \\
\pm 9.6\end{array}$ & $\begin{array}{c}29 \\
11.3 \\
+2.2 \\
5.97 \\
29 \\
\\
171.5 \\
\pm 14.1\end{array}$ & $\begin{array}{l}16 \\
10.1 \\
+1.5 \\
10.56 \\
15 \\
\\
112.1 \\
\pm 14.3\end{array}$ & $\begin{array}{c}10 \\
9.8 \\
\pm 1.9 \\
8.16 \\
10 \\
\\
119.9 \\
+13.2\end{array}$ & $\begin{array}{c}10 \\
11.1 \\
+2.0 \\
6.93 \\
10 \\
\\
202.8 \\
+51.2\end{array}$ \\
\hline
\end{tabular}

$N$ : normal rats.

Sm : normal rats + a manipulation after expulsion of 1 st fetus.

Smc : normal rats + a manipulation and a change after expulsion of 1 st fetus.

Sm $4 c$ : normal rats + a manipulation and a change after expulsion of 4 th fetus.

$S$ : normal rats + a manipulation and a stress after expulsion of 1 st fetus.

A - Adrenalectomized rats receiving physiological saline after expulsion of 1 st fetus.

$A^{-}+S:$ Adrenalectomized rats submitted to a stress saline after expulsion of 1 st fetus. 1 st fetus.

$A-+E$ : Adrenalectomized rats receiving $5 \mu \mathrm{g}$ of epinephrin subcutaneously after expulsion of

The total length of the expulsion phase of the young born is given in table 1 . In the first group of normal rats, it differed $(P<0.01)$ according to the lots (lots $N, S m$, Smc, Sm4c, S). Control rats or those given a small stress (lots N, Sm, Smc, Sm4c) had an expulsion time lasting about $2 \mathrm{hrs}(\mathrm{P}>0.05)$. This differed from the animals which had the strongest stress (lot S) since their mean expulsion time was about $3 \mathrm{hrs}$ $(P<0.05)$.

As variability of the expulsion phases was very wide (standard error : 7.8 to $16.4 \mathrm{~min}$.), the distributions of the expulsion intervals of two successive births have been compared among the different lots. Figures 1 and 2 show these distributions for 

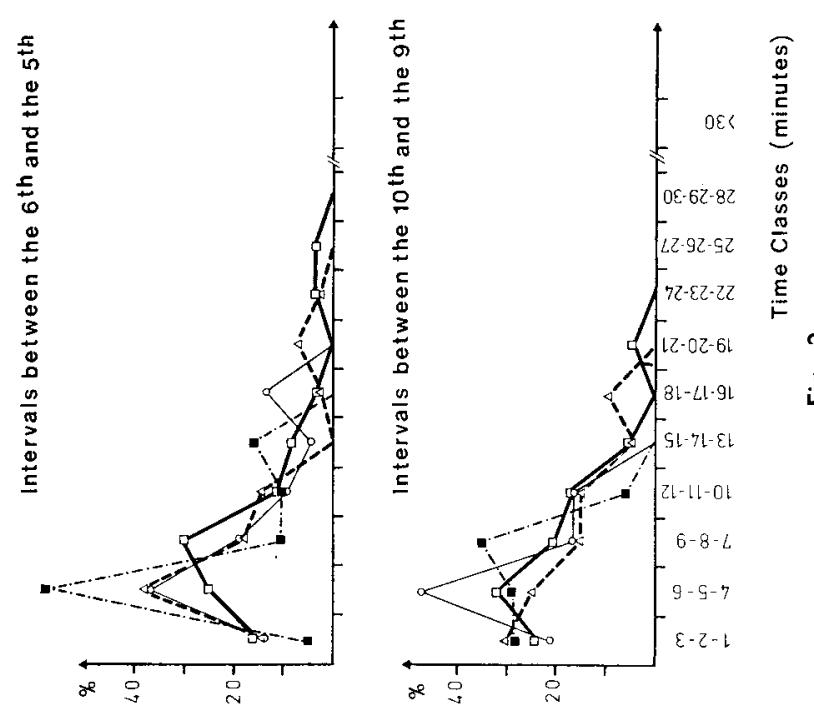

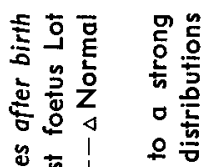

岛部 它可

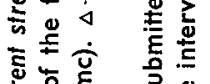

i

은은

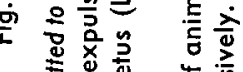

है

灵立 就

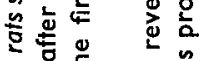

혼은

흫ㅎㅎㅎ음

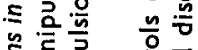

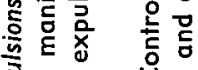

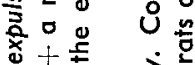

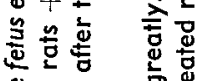

可

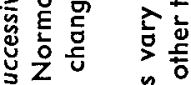

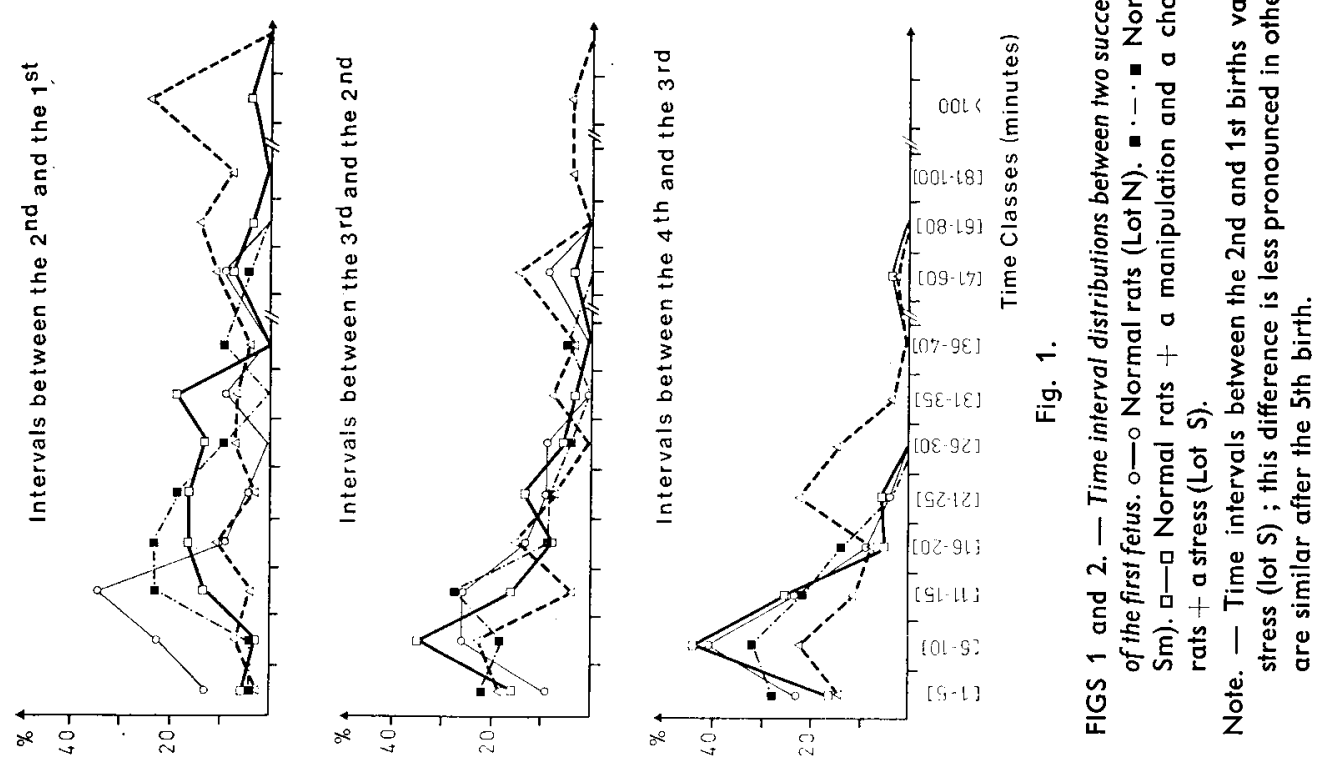


normal rats submitted to a stress after the birth of the first pup. These distributions were analyzed by the Chi-square test after grouping the time classes (Snedecor and Cochran, 1957). Thus, all lots of stressed animals differed from the normal rats $(P<0.01)$ as to the interval observed between the first and second births. For the following birth intervals, only that between the third and fourth births in rats suffering the strongest stress (lot $S$ ) differed from the others (lots $N, S m, S m c$ ) $(P<0.05)$.
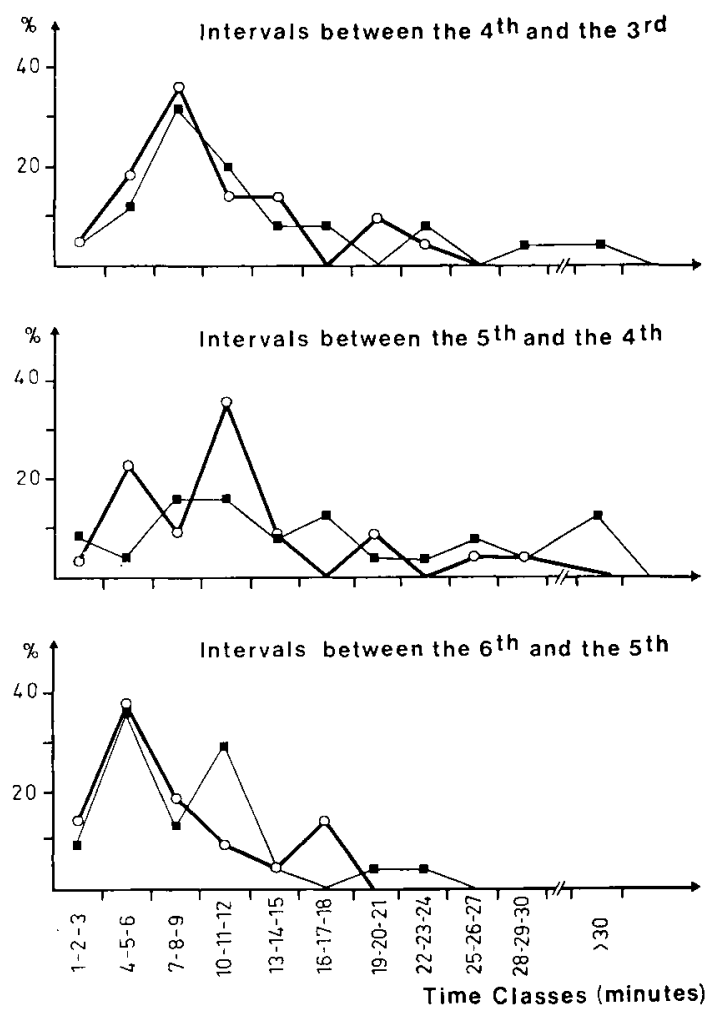

FIG. 3. - Time interval distributions between expulsion of the 4 th and $3 \mathrm{rd}$, $5 \mathrm{th}$ and $4 \mathrm{th}$ and $6 \mathrm{th}$ and $5 \mathrm{th}$ fetuses of normal rats submitted to a stress offer the 4 th birth. $0-0$ Normal rats (Lot N). =-- Normal rats + a manipulation and a change after the expulsion of the 4th foetus (Lot Sm4c).

Figure 3 presents the time interval distribution of normal rats (lot $N$ ) and of animals stressed after the fourth birth (lot Sm4c). The analysis shows no difference between these 2 lots $(P>0.05)$. As a consequence of stress, the stillbirth rate in the first group of normal rats differed with the lot (table $1 ; 0.05>P>0.01$ ). Perinatal mortality depended on the type of stress. It only increased by 1 p. 100 in lots Sm, Smc and $\operatorname{Sm} 4 \mathrm{c}(\mathrm{P}>0.05)$; when stronger stress was applied, it was higher and affected 6 p. 100 of the newborn (lot $S)(0.05>P>0.01)$. Figure 4 , which includes the 5 groups 
of normal rats, shows that this perinatal mortality is related to duration of the labor expulsion phase.

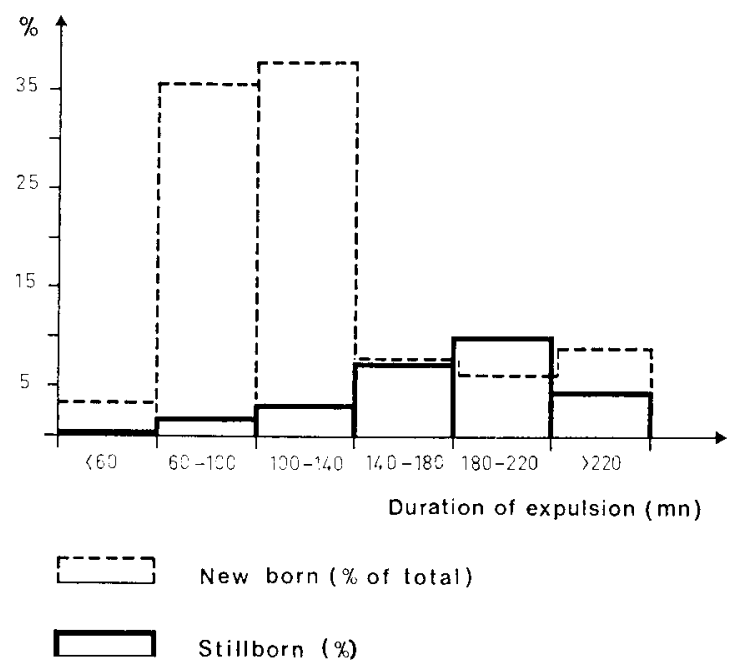

FIG. 4. - Relationship between expulsion duration and stillbirth rate in normal rats.

After adrenalectomy, with or without a stress after expulsion of the first fetus (lots $A^{-}$and $A^{-}+S$ ), the total lenght of the expulsion phase did not differ from that of the normal rats (lot $N)(P>0.05)$. But figure 5 shows that the mean increase of expulsion time at each additional birth was slightly higher in the adrenalectomized rats than in the normal ones. This was partially due to the greater variability of the first two intervals between the first three births (fig. 5) in lots $\mathrm{A}^{-}$and $\mathrm{A}^{-}+\mathrm{S}$. As the number of animals was too small in these lots, interval distributions have not been compared to the control. On the other hand, figure 5 shows the close evolution of the mean increase of expulsion time at each additional birth in normal rats submitted to a strong stress (lot 5) and in adrenalectomized rats receiving $5 \mu \mathrm{g}$ of epinephrin. After adrenalectomy,

TABLE 2

Prolificacy and stillbirth rate of rats submitted to two different light regimes and to pre-labor stress (Experiment II)

\begin{tabular}{|c|c|c|c|c|c|}
\hline \multirow{2}{*}{$\begin{array}{l}\text { Light Regime } \\
\text { Lots }\end{array}$} & \multicolumn{3}{|c|}{$14 L-10 D$} & \multicolumn{2}{|r|}{$8 \mathrm{~L}-16 \mathrm{D}$} \\
\hline & Control & $\begin{array}{l}\text { Stress at } 10 \text { a. m. } \\
\quad \text { on day } 22\end{array}$ & $\begin{array}{l}\text { Stress af } 10 \mathrm{a} . \mathrm{m} . \\
\text { on day } 22 \\
+ \text { stress at } 6 \mathrm{a} . \mathrm{m} . \\
\text { on day } 23\end{array}$ & Control & $\begin{array}{l}\text { Stress at } 10 \text { a. m. } \\
\quad \text { on day } 22\end{array}$ \\
\hline $\begin{array}{l}n \\
\text { Prolificacy (m } \\
\pm S d) \ldots \ldots . \\
\text { p. } 100 \text { of dead }\end{array}$ & $\begin{array}{c}78 \\
9.5 \pm \frac{ \pm}{3.1} 3.0\end{array}$ & $\begin{array}{c}58 \\
9.6 \frac{ \pm}{2.7} 2.9\end{array}$ & $\begin{array}{c}52 \\
10.2 \pm 2.3 \\
1.3\end{array}$ & $\begin{array}{c}62 \\
10.0 \pm \frac{2.9}{2.9}\end{array}$ & $\begin{array}{c}51 \\
10.8 \pm 2.6 \\
4.8\end{array}$ \\
\hline
\end{tabular}


the administration of $5 \mu \mathrm{g}$ of epinephrin noticeably lengthened the expulsion phase as compared to animals given physiological saline or the formalin solution (lots $\mathrm{A}^{-}$and $A^{-}+E$ ) (table 1). In some cases not reported in detail here, stronger inhibition was observed with a double dose of epinephrin $(10 \mu \mathrm{g})$. The adrenalectomy in this experiment affected stillbirth rate as compared to the controls $(P<0.01)$ (table 1$)$. But there was no difference among the three lots of adrenalectomized females $(P>0.05)$

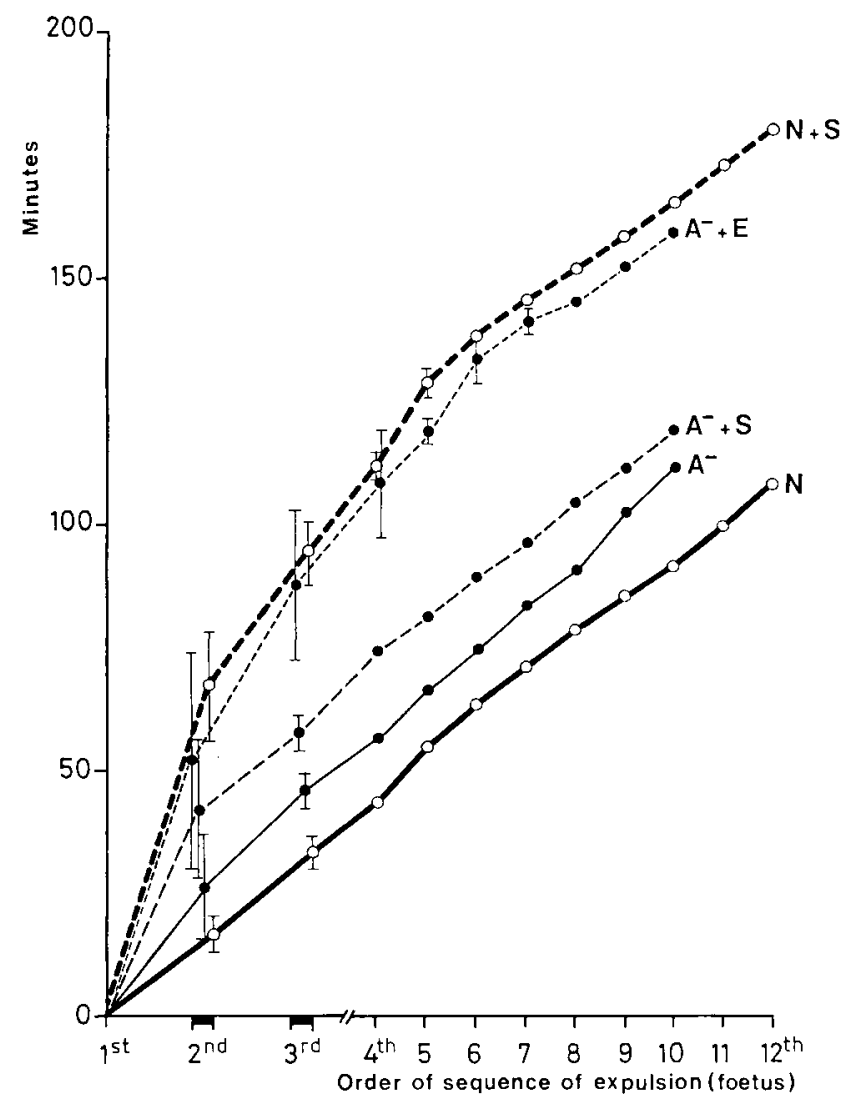

FIG. 5. - Mean increase of expulsion duration according to order of fetal birth in normal and adrenalectomized rats. Stress effect or action of $5 \mu \mathrm{g}$ of epinephrin after expulsion of 1 st fefus. o- o N : Normal rats $\circ---\circ N+S:$ Normal rats + a stress after the expulsion of the first foetus. $\bullet-\bullet A-:$ Adrenalectomized rats. $\bullet-\ldots A-+S$ : Adrenalectomized rats + a stress after the expulsion of the first foetus. $\bullet \cdots \bullet A^{-}+E:$ Adrenalectomized rats $+5 \mu \mathrm{g}$ of epinephrine after the expulsion of the first foetus.

B) Experiment 11 .

In the 2 groups of animals corresponding to the 2 light régimes, there was no difference $(P>0.05)$ in prolificacy and stillbirth rate between the lots (table 2$)$. However, figures 6 and 7 show that the hourly frequencies of parturition (onset of parturition) depended on the photoperiod $(P<0.01)$. 
In the short-day lot (8L-16D), 69 p. 100 of parturitions started before 8 p. m. on day 22 of pregnancy, and 85 p. 100 before 4 a. m. on day 23. After a stress at 10:00 a. m. on day 22, 94 p. 100 of the parturitions occurred before $8 \mathrm{p} . \mathrm{m}$. on the same day. This difference $(0.05>P>0.01)$ between control and stressed rats is shown on figure 6 .

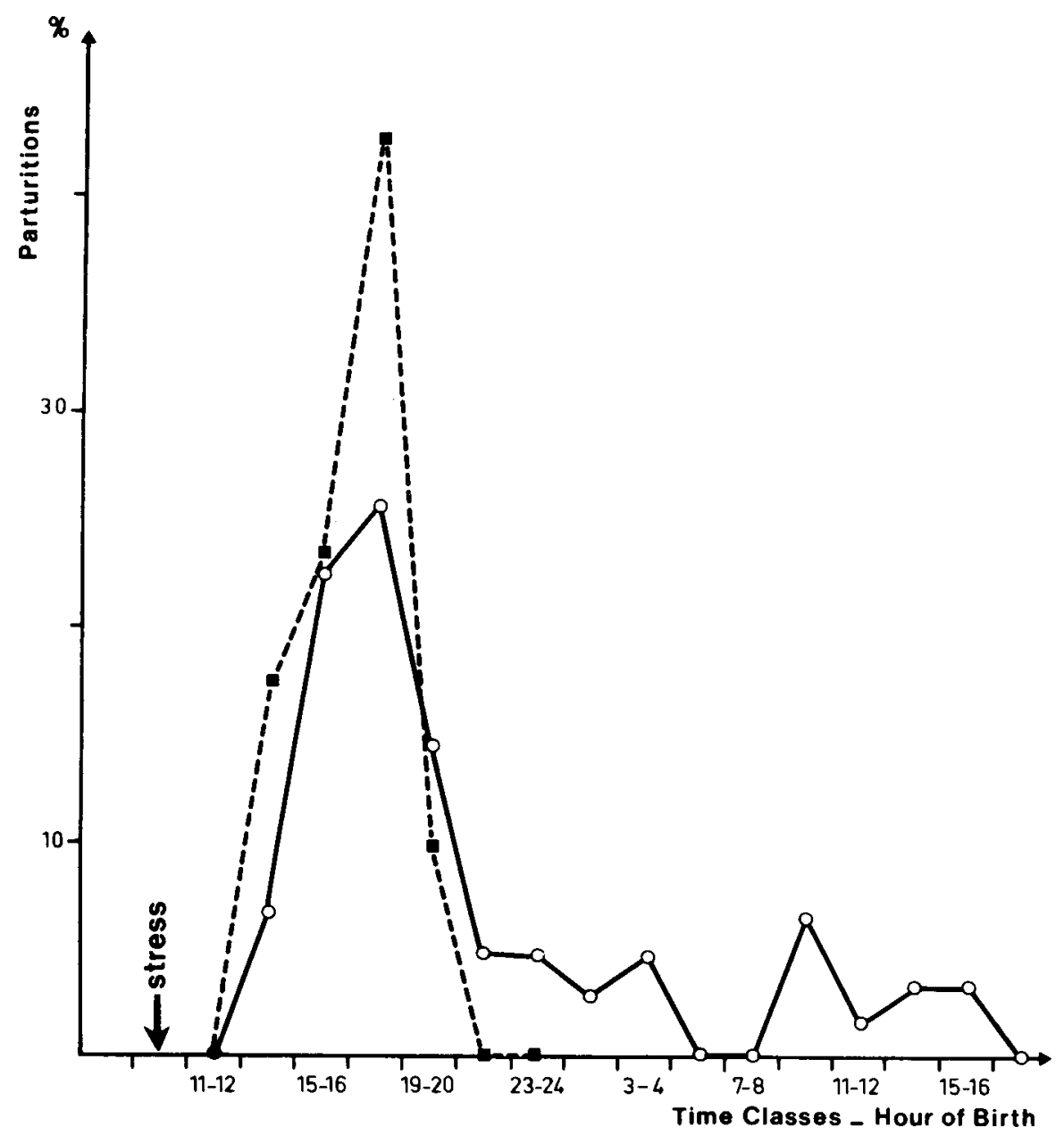

FIG. 6. - Parturition rhythm of rats exposed to shorf-day period ( $8 \mathrm{hrs} \mathrm{light} 16 \mathrm{hrs}$ darkness). Influence of pre-labor stress. $0-0$ Control. -.... Stress at $10 \mathrm{~h}$ on the 22th day of pregnancy.

In the normal régime lot (14L-10D), most of the parturitions were spread over 2 main periods : 50 p. 100 of them occurred earlier on day 22 of pregnancy (between $11 \mathrm{a} . \mathrm{m}$. and 8 p. m.) ; 36 p. 100 took place later on day 23 (between 4 a. m. and 12 a. m.). After one or two successive stresses, the first parturitions, which began during the 
first period, were not affected; the second occurred a little earlier than the controls on day 23 of pregnancy (fig. 7).

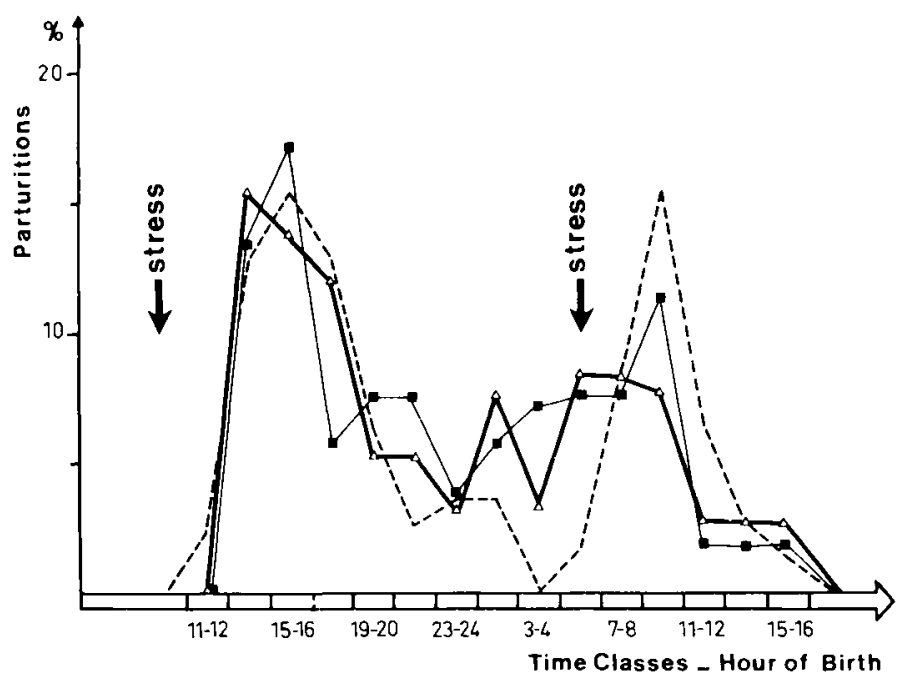

FIG. 7. - Parturition rhythm of rats exposed to mean day period (14 hrs light-10 hrs darkness). Influence of pre-labor stress. - - Control. $\Delta-\Delta$ Stress at $10 \mathrm{~h}$ on the 22th day of pregnancy. - - Stress at $10 \mathrm{~h}$ on the 22 th and at $6 \mathrm{~h}$ on the 23th day of pregnancy.

\section{Discussion.}

In rat, labor lasts about 3 to 4 hrs (Fuchs, 1969 ; Fuchs and Poblete, 1970). It is preceded by a change in uterine activity and oxytocin sensitivity which occurs about 24 to $48 \mathrm{hrs}$ beforehand (Fuchs, 1969). These muscular changes lead to expulsion of the litter in about $2 \mathrm{hrs}$, and the results observed in normal rats in Experiment I confirm earlier data (Fuchs, 1969 ; Boer et al., 1975 ; Naatkgeboren and Bontekoe, 1976). The noticeable variability of the expulsion phase of labor was mainly due to the time intervals between the first three births (fig. 1), even though there was a positive correlation between the total length of expulsion and the litter size. This correlation was 0.39 in lots of the first experiment which had the same total expulsion time.

As shown in Experiment I, two different stress effects can be obtained, depending on the type of stress applied at birth and the time of its application. When applied at the onset of pup expulsion, the effects of stress vary with its intensity. A simple manipulation or a change of territory does not affect the total length of expulsions (table 1), but time interval variability increases between the first births. Considering the distribution curves of these intervals (fig. 1) and total expulsion durations, the effect of such stresses can be interpreted as biphasic with an inhibition just after the stress, followed by a rebound effect. The great variability of the data also suggests that the first or the second effect is more or less marked according to the individual. At the same moment of labor, a strong stress has mainly an inhibitory effect since it prolongs the whole expulsion phase significantly (table 1). This prolongation was due to the longer 
time intervals between the first births (fig. 1) since there was no apparent effect on the last ones (fig. 2). Finally a stress seemed to have little or no influence when given at the end of the expulsion phase (table 1, fig. 3).

These results demonstrate that a stress at this stage of pregnancy has not only an inhibitory effect on the course of labor, as has often been emphasized (Newton et al., 1968 ; Naaktgeboren and Bontekoe, 1976), they also show this effect can be attributed to epinephrin secretion since $5 \mu \mathrm{g}$ of this catecholamine produced the strong stress response of normal rats in adrenalectomized ones (fig. 5). These data agree with observations obtained on the uterine activity of parturient rabbit or sheep (Naaktgeboren and Bontekoe, 1976). But epinephrin causes three types of response in the myometrium and it has been stated that they depend on the hormonal status of the animal. Abe (1970) gives evidence that the rat uterus has both alpha and beta receptors and that their number in that organ may be steroid-dependent (Williams and Lefkowitz, 1977 ; Roberts et al., 1977). The hormonal conditions in which labor occurs and progresses are well known in the rat. In this species, progesterone inhibits parturition and prolongs gestation (Deansley, 1956 ; Edgreen and Peterson, 1966 ; Picon, 1968 ; Acker, 1969 ; Csapo and Wiest, 1969 ; Herrenkohl and Lisk, 1973 ; Vermouth and Deis, 1975) ; its level in the plasma (Grota and Eik-Ness, 1967 ; Csapo and Wiest, 1969 ; Kuhn, 1969 ; De Lauzon et al., 1974 ; Labhsetwar and Watson, 1974 ; Martin et al., 1977 : Pepe and Rothchild, 1974 ; Shaikh ef al., 1977) and in the uterus (Csapo and Wiest, 1969 ; Davies and Ryan, 1973) decreases until birth.

This decrease is due to an influence of PGF $_{2 x}$ (Chester et al., 1972 ; Labhsetwar and Watson, 1974 ; Dukes et al., 1974 ; Buckle and Nathanielsz, 1975 ; Strauss, 1975) which is controlled by estrogen secretion (Yoshinaga ef al., 1969 ;Waynforth et al., 1972 ; Labhsetwar and Watson, 1974 ; De Lauzon et al., 1974), estrogen being necessary for the normal progress of parturition in rat (Jost, 1959 ; Acker, 1969 ; Csapo and Wiest, 1969 ; Catala and Deis, 1973). Furthermore, labor is sustained by secretion of PGF $_{2 \alpha}$ (Dukes et al., 1974 ; Labhsetwar and Watson, 1974 ; Shaikh et al., 1977). Thus, it may be postulated that our experiments were done under uterine estrogenic impregnation at a time when $\mathrm{PGF}_{2 \alpha}$ secretion was active and progesterone level was falling.

The effects observed in our results can also be related to the level of epinephrin secretion, which depends on the stress, and to the initial uterine content of this catecholamine. In a recent study, Maltier and Cavaille (1975) demonstrated that abnormal or delayed parturitions in rat are associated with high uterine epinephrin content. This level decreases normally during the last days of pregnancy under the influence of steroids (Maltier and Cavaillé, 1978). So the progressive decrease of uterine epinephrin level, necessary to the progression of labor, probably explains why time intervals between the first births show greater variability, and why stress only has a noticeable action before or just at the onset of the expulsion phase.

The maternal epinephrin secreted by the adrenals or bound in the uterus is probably not the only factor involved. As indicated by data on adrenalectomized rats, stress can cause endocrine changes resulting in more variable time intervals between births (Experiment I, fig. 5). This is possibly due to modification of fetal neurohypophyseal secretion since Swaab ef al. (1977) observed protracted labor after aspiration of fetal brain or in Brattleboro rats homozygous for diabetus insipidus. These authors 
have suggested that arginin-vasotocin would be involved. In another study (Boer et al., 1975), a change of pulsatile oxytocin release has also been invoked as a possibility.

It is interesting to note that maternal behavior was affected by a strong stress (lot $S$ : the stressed mothers often paid no attention to the first delivered pup until the birth of others) ; this behavior may be related to neurohormone secretion and to the course of labor.

In this experiment, the prolificacy of adrenalectomized animals was slightly lower than the controls. This agrees with the study of Thoman ef al. (1970). On the other hand, stillbirth rate was higher after adrenalectomy and, in our conditions, seemed unrelated to the treatment. By comparison, in the normal rats there was a relationship between prolongation of labor and incresae of perinatal mortality (fig. 4). This agrees with the observations of Newton ef al. (1968) in mice or of Friend ef al. (1962) and Randall (1972) in pigs.

In contrast with the data of Experiment I, a stress applied before onset of labor appears to have only a stimulating influence. This is the case in Experiment II in which stress advanced the onset of the last parturitions with no apparent effect on the rats which would enter labor in day 22 of pregnancy. This influence was probably due to the hormonal status of the animals since stress was applied before labor in most cases. However, it can also be assumed that stress-induced secretion of catecholamines and corticosteroids is followed later by a more rapid depletion of uterine epinephrin content, as suggested by the results of Maltier and Cavaille $(1975,1978)$. Furthermore, it seems that general conditions interfere with stress efficacity. In our conditions, this positive influence appears more significant under the short-day régime (figs 6,7 ) ; more parturitions usually occurred during day 22 of pregnancy than under control conditions.

This effect of the light régime on the time of parturition is highly important. It has often been underlined in this species (Naaktgeboren and Slijper, 1970 ; Mitchell and Yochim, 1970 ; Boer ef al., 1975 ; Lincoln and Porter, 1976). However, relative parturition distributions during the last days of gestation are not always in agreement and they differ from our observations (Mitchell and Yochim, 1970 ; Lincoln and Porter, 1976). These differences will be discussed elsewhere (Bosc and Nicolle, in press).

The whole of the data suggest that the endocrine events leading to parturition in the rat are somehow regulated by general environmental conditions and that there may be a synergism or some coordination with the changes induced by a stress.

Reçu en mai 1978.

Accepté en août 1978.

Résumé. L'effet d'un stress sur le déroulement du travail ou sur le moment de la parturition a été étudié chez la ratte parturiente au cours de deux expériences selon qu'il a été appliqué pendant ou avant le travail. Ainsi, dans la première expérience, différents stress ont été appliqués après l'expulsion du $1^{\mathrm{er}}$ fœtus. Seul un stress fort rallonge significativement la durée totale d'expulsion en affectant principalement les intervalles entre les premières naissances. Une simple manipulation de l'animal ou un changement de territoire ne modifient pas la durée totale d'expulsion mais ils entrainent une plus grande variabilité du moment de la naissance du $2^{\mathrm{e}}$ fœtus. La comparaison des résultats obtenus chez la ratte surrénalectomisée montre que l'effet inhibiteur du stress fort est vraisemblablement dô à une sécrétion d'adrénaline par les surrénales maternelles. Dans la deuxième expérience, 
le stress a été appliqué avant le travail à des rattes normales soumises à deux régimes lumineux différents. Le traitement a eu une influence stimulatrice plus ou moins marquée selon le régime lumineux. Cette influence s'est essentiellement manifestée sur les parturitions qui auraient do se produire normalement le $23^{\mathrm{e}}$ jour de la gestation.

\section{References}

$A B E Y ., 1970$. The hormonal control and the effects of drugs and ions on the electrical and mechanical activity of the uterus, 396-417. In BÜLBRING E., BRADING A. F., JONES A.W., TOMITA T., Smooth muscle, Chap. 13, Edward Arnold Publ. Ltd London.

ACKER G., 1969. A propos du déterminisme hormonal de la mise-bas chez la Ratte ; rôle de l'oestradiol. C. R. Acad. Sci. Paris, Sér. D, 268, 2196-2199.

BLEICHER N., 1962. Behavior of the bitch during parturition. J. Amer. vet. Med. Assoc., 10, 1076-1082.

BOER K., LINCOLN D.W., SWAAB D. F. Effects of electrical stimulation of neurohypophysis on labour in the rat. J. Endocr., 65, 163-176.

BUCKLE J.W., NATHANIELSZ P.W., 1975. A comparison of the characteristics of parturition induced by Prostaglandin $F_{2 \alpha}$ infused intraortically with those following ovariectomy in the rat. J. Endocr., 64, 257-266.

CATALA S., DEIS R. P., 1973. Effect of oestrogen upon parturition maternal behaviour and lactation in ovariectomized pregnant rats. J. Endocr., 56, 219-225.

CHESTER R., DUKES M., SLATER S. R., WALPOLE A. L., 1972. Delay of parturition in the rat by antiinflammatory agents which inhibit the biosynthesis of prostaglandins. Nature, 240, 37-38.

CSAPO A. I.,WIEST W. G., 1969. An examination of the quantitative relationship between progesterone and the maintenance of pregnancy. Endocrinology, 85, 735-746.

DAVIES I J., RYAN K. J., 1973. The modulation of progesterone concentration in the myometrium of the pregnant rat by changes in cytoplasmic receptor protein activity. Endocrinology, 92, 394-401.

DEANSLEY R., 1956. The endocrinology of pregnancy and foetal life, 891-1063. In PARKES S. A., Marshall's physiology of reproduction, Vol. 3, Longmans, Green and Co, London.

DE LAUZON F., ULRICH F., VANDEL S., CITTANOVA N., JAYLE M. F., 1974. Determination of progesterone and of free and conjugated estrogens in pregnant and pseudo-pregnant rats. Steroids, 24, 31-40.

DUKES M., CHESTER R., ATKINSON P., 1974. Effects of oestradiol and prostaglandin $F_{2 \alpha}$ on the timing of parturition in the rat. J. Reprod. Fert., 38, 325-334.

EDGREEN R. A., PETERSON D. L., 1966. Part delayed in rats with progestagens. Proc. Soc. exp. Biol. Med., 23, 867-869.

FREAK M. J., 1962. Abnormal conditions associated with pregnancy and parturition in the bitch. Vet. Rec., 74, 1323-1339.

FRIEND D.W., CUNNINGHAM M. M., NICHOLSON J.W. G., 1962. The duration of farrowing in relation to the reproductive performance of Yorkshire sows. Can. J. comp. Med. vet. Sci., 26, 127-130.

FUCHS A. R., 1969. Uterine activity in late pregnancy and during parturition in the rat. Biol. Reprod., 1, 344-353.

FUCHS A. R., POBLETE V. P., 1970. Oxytocin and uterine function in pregnant and parturient rats Biol. Reprod., 2, 387-400.

GROTA L. J., EIK-NESS K. B., 1967. Plasma progesterone concentrations during pregnancy and lactation in the rat. J. Reprod. Fert., 13, 83-91.

GUILLEMIN R., CLAYTON G.W., SMITH J. D., LIPSCOMB M. S., 1958. Measurement of free corticosteroids in rat plasma : Physiological validation of a method. Endocrinology, 63, 349-358.

HERRENKOHL L. R., LISK R. D., 1973. Effects on lactation of progesterone injection administered before and after parturition in the rat. Proc. Soc. exp. Biol. Med., 142, 506-510.

JEGO P., LESCOAT G., MANIEY J., 1971. Influence de la gestation sur la réponse du complexe hypothalamo-hypophyso-surrénalien aux agressions. C. R. Acad. Sci. Paris, Sér. D, 272, $1133-$ 1136. 
JOST A., 1959. Développement des foetus, accouchement et allaitement chez des rattes castrées en fin de gestation. Arch. Anat. micr. Morph. exper., 48, 133-140.

KUHN M. J., 1969. Progesterone withdrawal as the lactogenic trigger in the rat. J. Endocr., 44, 39-54.

LABHSETWAR A. P., WATSON D. J., 1974. Temporal relationship between secretory patterns of gonadotropins estrogens progestins and prostaglandin $\mathrm{F}_{2 \alpha}$ in periparturient rats. Biol. Reprod. 10, $103-110$.

LINCOLN D.W., PORTER D. G., 1976. Timing of the photoperiod and the hour of birth in rats. Noture, 260, 780-781.

MALTIER J. P., CAVAILLÉ F., 1975. Effects of injections of monoamine oxidase inhibitor or saline into the uterus in late pregnancy on uterine catecholamine levels related to abnormal parturition. J. Endocr., 67, 371-383.

MALTIER J. P., CAVAILLÉ F., 1978. Effects of ovariectomy progesterone and oestrogen on uterine catecholamine concentrations in relation to parturition in rats. J. Endocr., 76, 93-100.

MARTIN C. E., CAKE M, H., HARTMANN P. E., COOK I. F., 1977. Relationship between foetal corticosteroids, maternal progesterone and parturition in the rat. Acta endocr., 84, 167-176.

MITCHELL J. A., YOCHIM J. M., 1970. Influence of environmental lighting on duration of pregnancy in the rat. Endocrinology, 87, 472-480.

NAAKTGEBOREN C., SLIJPER E. J., 1970. Biologie des Geburt eine Ein-führung in die vergleichende Geburtskunde. Paul Parey, Hamburg und Berlin.

NAAKTGEBOREN C., BONTEKOE E. H. M., 1976. Vergleichend-geburstkundliche betrachtungen und experimentelle untersuchungen über psychosomatische störungen der Schwangerschaft und des Geburtsablaufes. Z. Tierz. ZüchtBiol., 93, 264-320.

NEWTON N., FOSHEE D., NEWTON M., 1966. Parturient mice. Effect of environment on labor Science, 151, 1560-1561.

NEWTON N., PEELER D., NEWTON M., 1968. Effect of disturbance on labor. An experiment with 100 mice with dated pregnancies. Am. J. Obstet. Gynecol., 101, 1096-1102.

PEPE G. J., ROTHCHILD I., 1974. A comparative study of serum progesterone levels in pregnancy and in various types of pseudopregnancy in the rat. Endocrinology, 5, 275-279.

PICON L., 1968. Teneur en lipides du fœtus de rat et du nouveau-né : action des glandes endocrines. J. Physiol., 60, 19-296.

RANDALL G. C. H., 1972. Observations on parturition in the sow. Il factors influencing still-birth and perinatal mortality. Vet. Rec., 90, 183-186.

RAKOTO-RATSIMAMANGA A., RATSIMAMANGA-URVEG S., MIGEON-DUREUIL M., $1974 . \quad$ Nouvelle contribution à l'étude de la survie de la ratte adulte surrénalectomisée et castrée. C. R. Acad. Sci. Paris, Sér. D, 278, 901-905.

ROBERTS J. M., INSEL P. A., GOLDFIEN R. D., GOLDFIEN A., 1977. $\alpha$-adrenoreceptors but not $\beta$-adrenoreceptors increase in rabbit uterus with oestrogen. Nature Lond., 270, 624-625.

ROSSDALE P. D., SHORT R. V., 1967. The time of foaling of thoroughbred mares. J. Reprod. Fert., 13, 341-343.

SHAIKH A. A., NAQVI R. H., SAKSENA S. K., 1977. Prostaglandins E and F in uterine venous plasma in relation to peripheral plasma levels of progesterone and $20 \alpha$-hydroxyprogesterone in the rat throughout pregnancy and parturition. Prostaglandins, 13, 311-320.

SIGNORET J. P., 1969. Verhalten von Schweinen, 263-330. In PORZIG E., Das Verhalfen. Landwirschaftlicher Nutziere. Veb. Deutscher Landwirtschaftsverlag, Berlin.

SNEDECOR G.W., COCHRAN W. G., 1957. Statistical methods. 6th ed., The lowa State Univ. Press, Ames, lowa, USA.

STRAUSS J. F., SOKOLOSKI J., CAPLOE P., DUFFY P., MINTZ G., STAMBAUGH R. L., $1975 . \quad$ On the role of prostaglandins in parturition in the rat. Endocrinology, 96, 1040-1043.

SWAAB D. F., BOER K., HONNEBIER W. J., 1977. The influence of the fetal hypothalamus and pituitary on the onset and course of parturition, 379-393. In the fetus and birth, Ciba Found. Symp. Elsevier-Excerpta Medica, North Holland, Amsterdam.

THOMAN E. B., SPROUL M., SEELER B., LEVINE S., 1970. Influence of adrenalectomy in female rats on reproductive processes including effects on the foetus and offspring. J. Endocr., 46, 297 303.

VAN GOCH J. J., DE WIELD D., SCHÖNBAUM E., 1963. Adrenocorticotropic activity in the rat assessed by in vivo and in vitro indices. Am. J. Physiol., 205, 1083-1088. 
VERMOUTH N. T., DEIS R. P., 1975. Inhibitory effects of progesterone of the lactogenic and abortive action of prostaglandin $F_{2 \alpha}$. J. Endocr., 66, 21-29.

VERNIKOS-DANELLIS J., ANDERSON E., TRIGG L., 1966. Changes in adrenal corticosterone concentrations in rats. Method of bioassay for ACTH. Endocrinology, 79, 624-630.

WAYNFORTH H. B., POPE G. S., HOSKING Z. D., 1972. Secretion rates of oestrogens into the ovarian venous blood of pregnant rats. J. Reprod. Fert., 28, 191-196.

WILLIAMS L. T., LEFKOWITZ R. J., 1977. Regulation of rabbit myometrial alpha adrenergic receptors by estrogen and progesterone. J. clin. Invest., 60, 815-818.

YOSHINAGA K., HAWKINS R. A., STOCKER J. F., 1969. Estrogen secretion by the rat ovary in vivo during the estrous cycle and pregnancy. Endocrinology, 85, 103-112. 